\title{
ХОД ЭКСПЕРИМЕНТА ПО ВВЕДЕНИЮ КУРОРТНОГО СБОРА НА ТЕРРИТОРИИ КАВКАЗСКИХ МИНЕРАЛЬНЫХ ВОД
}

\author{
(C) 2019 Хурмагов Ибрагим Алиевич \\ Российская академия народного хозяйства и государственной службы при Президенте РФ, \\ Северо-Кавказский институт, Россия, Пятигорск \\ E-mail: Ibragim-kn@mail.ru
}

Статья посвящена анализу финансовых интересов отдыхающих и туристов, а также хозяйствующих субъектовв связи с введением курортного сбора на рекреационной территории.

Подводятся промежуточные итоги проводимого в РФ эксперимента по введению курортного сбора, на примере санаторно-курортного комплекса Кавказских Минеральных Вод (КМВ).

Автор отмечает, что эксперимент положит начало новому толчку в развитии и благоустройстве городов-курортов КМВ и в целом Ставропольского края за счет целенаправленного использования дополнительного источника финансирования.

Ключевые слова. Курортный сбор, эксперимент, правовая база, ставки, льготные категории, результаты, динамика потока отдыхающих, направления использования средств, эффективность.

Как известно, в России экспериментально с 2018 года был введен курортный сбор. Идея его применения в нашей стране вызвала бурную дискуссию. Следует отметить, что такая практика не является исключительной не только в мире, но и в России, где с 1991 по 2004 году уже применялась подобная финансовая повинность, однако она была признана неэффективной и отменена. Сейчас законодатели РФ учли прошлый опыт и пожелания заинтересованных лиц и решили вновь, в качестве эксперимента, ввести курортный сбор. Туристический налог платят постояльцы гостиниц в Испании, Италии, Греции и в других странах.

В данной статье рассмотрены промежуточные результаты эксперимента по введению курортного сбора на примере субрегиона Ставропольского края - Кавказских Минеральных Вод (КМB), обладающего рекреационной составляющей.

Прежде всего, уточним, что же представляет собой эксперимент по введению курортного сбора. Для этого потребуется обращение к правовой базе. А именно, в соответствии с Федеральным законом от 29.07.2017 № 214-Ф3 «О проведении эксперимента по развитию курортной инфраструктуры в республике Крым, Алтайском крае, Краснодарском крае и Ставропольском крае», был принят нормативный акт субъекта РФ - Закон Ставропольского края от 08.12.2017 г. № 130-К3 «О некоторых вопросах проведения эксперимента по развитию курорт- ной инфраструктуры в Ставропольском крае», регламентирующий введение курортного сбора на территории городов-курортов: Ессентуки, Железноводск, Кисловодск, Пятигорск. Курортный сбор - это обязательный платеж, который физическое лицо обязано уплатить за каждые 24 часа использования курортной инфраструктуры $[1,2]$.

Курортный сбор в России взимается только с физических лиц, достигших совершеннолетия, как с граждан РФ, так и с иностранцев. Организации и индивидуальные предприниматели не являются плательщиками курортного сбора, поскольку это - субъекты бизнеса. Оплата осуществляется только в случае, если отдыхающие и туристы более чем на 24 часа остановятся в объектах размещения, из числа тех, которые принимают участие в эксперименте. К объектам размещения относятся не только санатории, профилактории, гостиницы и отели, но и жилые дома, квартиры, комнаты, пригодные для временного проживания.

Высказывались опасения, что это финансовое новшество негативно отразится на потоке отдыхающих и туристов. Однако на практике оказалось, что большая часть гостей на курортный сбор реагирует вполне благожелательно. Первая транзакция - 13 млн. руб. прошла 28 мая 2018 г., 76\% отдыхающих Ставрополья оплатили курортный сбор; 16\% воспользовались своим правом на льготу, подтвердив его документально и были освобождены от оплаты. Кстати, рас- 
считывать на это могут 19 категорий льготников. К таким физлицам отнесены: местные жители (действует полное освобождение от платежа); несовершеннолетние; инвалиды; ветераны и другие. Точный их перечень и размер тарифов нужно будет уточнять в региональных нормативных актах. Хотя по льготникам возникает больше всего вопросов: какие документы считаются подтверждающими льготу, а какие во внимание не принимаются. Думаем, что со временем подобные нюансы будут четко отработаны.

Таким образом, с 1 мая 2018 года в Ставропольском и Алтайском краях с отдыхающих стали взимать курортный сбор; с 16 июля его ввели в Краснодарском крае. А власти Крыма отложили нововведение на год, т.е. там курортный сбор введен с 1 мая 2019 года в муниципальных образованиях: Ялта; Евпатория; Алушта; Судак; Феодосия; Саки; Черноморский район.

В настоящее время определены ставки курортного сбора по регионам: Алтайский край 30 руб. с человека в сутки; Республика Крым - 10 руб.; Краснодарский край - 10 руб.; Ставропольский край - 50 руб. с человека в сутки. Значит, классическая санаторная путёвка на 21 день стала дороже на 1050 руб. Таким образом, на экспериментальных территориях сумма курортного сбора в 2018 году не превышала 50 руб. с человека в день. В последующем, сбор ограничен 100 руб. с отдыхающего в день. Размер курортного сбора может дифференцироваться по сезонам, времени пребывания отдыхающего, значения курортной зоны в соответствии с законодательством РФ о природных лечебных ресурсах и курортах, входящих в территорию эксперимента. Это значит, что, например, в зимний сезон сбор не производится. Возможно, что величина курортного сбора, например, за первую неделю пребывания, будет максимальной, а затем снижается поэтапно.

Методика расчета курортного сбора (Кс) предусматривает использование следующей формулы:

Кс $=$ Ст х Кдн - Дз,

где: Ст - ставка курортного сбора в сутки (руб.);

Кдн - количество дней фактического проживания в объекте размещения;

Дз - день заезда.

Например, гость заехал в санаторий 21.05.2018 г., а выехал - 31.05.2018 г. Сумма курортного сбора, взимаемая с него, составит 500 руб. (50 руб. х (11 дней фактического проживания - день заезда).

Правительство РФ поручило осуществлять сбор денег с отдыхающих операторам, т.е. всем юридическим лицам, индивидуальным предпринимателям и гражданам, оказывающим гостиничные, санаторные, пансионные и другие услуги по размещению отдыхающих на временное проживание.

Если эксперимент будет признан удачным, курортный сбор с отдыхающих и туристов введут и в других регионах. Однако это не имеет никакого значения при распределении дотаций муниципалитетам. В результате, бюджетная нагрузка на уход за городом и благоустройство увеличивается вдвое.

Безусловно, дополнительное финансирование развития курорта положительно скажется на качестве оказания рекреационных услуг. За счёт курортного сбора регионы планировали значительно пополнить бюджет в первый год эксперимента. На Алтае - 50 млн. руб., на Ставрополье 180 млн. руб., в Краснодарском крае - около 265 млн. руб. Тратить их можно будет только на развитие курортной инфраструктуры: благоустройство терренкуров, парков, питьевых бюветов, грязевых источников, набережных, пляжей и т.П.

Курортные города КМВ также возлагают немалые надежды на курортный сбор. Например, в Пятигорске уже проводят восстановительные работы в парке «Цветник». Цель - вернуть ему исторический облик.

Исследуя ход проводимого эксперимента, следует отметить, что, по словам губернатора, до конца 2018 года Ставропольский край должен был получить не менее 180 млн. руб. дополнительных средств, поскольку на территории Кавказских Минеральных Водах действуют 364 гостиницы на 15,5 тыс. мест и 138 санаториев на 35,4 тыс. мест единовременного размещения. Основу курортного лечения здесь составляют целебные источники 18 типов и 40 видов минеральной воды. В регионе работают около 30 туроператоров, занесенных в реестр Ростуризма. Анализ показал, что фактически от операторов края в 2018 году поступило около 168 млн. руб., из них на Кавминводах курортный сбор составил 163 млн. руб. В среднем, за каждый месяц поступало более 24 млн. руб. Всего же, с мая 2018 года, когда был введен курортный сбор, в четырёх городах-курортах субрегиона отдыхающие 
и туристы, а это свыше 263 тыс. человек, добровольно оплатили сбор [4].

Несмотря на это, в ходе реализации закона о курортном сборе, выявляются слабые звенья. В регионах очень много вопросов по администрированию курортного сбора: не разработана общая схема; когда собирать плату; кто должен осуществлять контроль над процессом.

Отели и санатории Кавказских Минеральных Вод обратились за разъяснением в региональное отделение Министерства по туризму. В ведении управления - 26 здравниц, а многие отдыхающие и туристы предпочитают бронирование задолго до начала отдыха. О том, что им придется уплатить курортный сбор, они не были оповещены. Кстати, ответственность за неуплату курортного сбора установлена законом «Об административных правонарушениях в Ставропольском крае», который применяется вместе с КоАП (в нем прописана процедура привлечения к административной ответственности). По закону за неуплату сбора предусмотрен штраф: для физических лиц - от 500 до 2000 руб.; для операторов за нарушение порядка и сроков взимания - от 5000 до 15000 руб. [3].

Все собранные в крае средства были направлены на благоустройство инфраструктуры курортов. Так, по материалам газеты «Ставропольская правда», первый объект курортной инфраструктуры, реконструированный на средства курортного сбора, предъявили гостям г. Железноводска. За 26 млн. руб. здесь благоустроили Лермонтовский терренкур вокруг горы Железной. А еще 2 млн. руб. курортного сбора направили на проектирование Каскадной лестницы, которая соединила верхнюю часть курортного парка с озером и, таким образом, в несколько раз увеличила обитаемую часть парка. Объем финансирования на эти цели составил 26 млн. руб.

В городе-курорте Ессентуки ведутся работы по благоустройству парка «Курортный», реконструируют партерную группу возле Курортного парка.

В Пятигорске, как было сказано выше, развернуты работы по реализации дизайнерского проекта в курортной зоне «Цветник». Объем поступлений на развитие курортной инфраструктуры на 2018 год в столице СКФО был запланирован в размере 37,1 млн. руб. В сентябре подвели итоги аукциона и заключили контракт на выполнение работ по благоустройству парка
«Цветник» на сумму 36,9 млн. руб. «Цветник»это знаковое для местных жителей и гостей место, визитная карточка города. После активных общественных обсуждений, рейтингового голосования и рассмотрения вопроса экспертами градостроительного совета, была утверждена концепция масштабного благоустройства и начались работы. Первый этап реконструкции был завершен к декабрю 2018 г. На аллее вдоль парка «Цветник» установлен паспорт объекта, разъясняющий, что все работы здесь выполняются за счет средств курортного сбора. На втором этапе реконструкции, который был запланирован на 2019 год, в парке высадят более 168 тысяч цветов, несколько сотен кустарников и деревьев. А также вернут на историческое место фонтан «Счастливый улов», благоустроят «поющий» фонтан, смотровые площадки и гроты.

В городе-курорте Кисловодске преобразят сразу несколько объектов - два терренкура и такое же количество скверов. К началу 2019 года объект вступил в эксплуатацию. Также деньги направлены на ремонт и реконструкцию прогулочных зон на улицах Урицкого и Коминтерна, скверов у памятников Ксении Ге и Дмитрию Тюленеву на Курортном бульваре. Следует отметить, что в самом начале эксперимента в Кисловодске на средства курортного сбора планировали обустроить пешеходные зоны на улице Герцена и проспекте Ленина. Таким образом город-курорт получил бы еще два парадных входа в Национальный парк «Кисловодский». Были представлены эскизные проекты, один из которых получил приз на международном градостроительном форуме в Ессентуках. Однако в официальных документах сказано, что реконструкция автодорог не входит в перечень объектов курортной инфраструктуры, на которые можно использовать средства курортного сбора. Курортный сбор нельзя использовать даже на благоустройство тротуаров и газонов. К сожалению, в перечень запретов входят и подземные переходы в курортной зоне. Хотя, по-нашему мнению, необходимо расширить перечень объектов, подпадающих под реконструкцию за счет курортного сбора. Подобные ситуации имеют место не только в Кисловодске. Так, в Железноводске при реконструкции терренкура, подпорные стенки оказались вне списка объектов, на которые можно тратить средства курортного сбора.

И еще выявлена одно несоответствие. В Ку- 
рортном парке г. Ессентуки есть 11 объектов, на которые средства курортного сбора нельзя использовать и вообще местные власти к ним не могут подступиться. Речь идет о федеральных, ведомственных и частных объектах. В результате, в одной части парка порядок, а рядом - неухоженность. Поэтому, по нашему мнению, реконструкция курортных зон должна проводиться всеобъемлюще и комплексно. А для этого нужны соответствующие законодательные акты. Аналогичные проблемы есть и в Курортном парке Железноводска. Но, похоже, часть из них удастся скоро решить. Уже достигнута предварительная договоренность о передаче муниципалитету четырех федеральных бюветов минеральной воды, расположенных в этом парке.

Выпадающие доходы и недобросовестная конкуренция - еще один важный и трудно решаемый вопрос. Обсуждается проблема взимания курортного сбора с местных жителей, сдающих приезжим свои квартиры и дома. Опираясь на архивные данные того же города-курорта Железноводска, можно констатировать, что в советское время около 30 процентов отдыхающих на курорте официально размещали в частном секторе. Сейчас соотношение примерно такое же. Единовременно в санаториях и гостиницах, где взимают курортный сбор, можно разместить шесть тысяч отдыхающих. Следовательно, еще примерно полторы тысячи живут на квартирах, владельцы которых, как частные лица, не платят никаких налогов и не взимают с постояльцев курортный сбор.

Разумеется, среди квартиросдатчиков нет желающих зарегистрироваться в качестве предпринимателей. В результате, местный бюджет недополучает солидные суммы, а санаториям и гостиницам приходится работать в условиях недобросовестной конкуренции. В ближайшее время ситуацию нормализовать не удастся. Для этого, по нашему мнению, необходимо внести изменения в законодательные акты, причем, не только в местные и региональные, но и в федеральные. Интересен факт выявленных архивных сведений, что в советское время все железноводские здравницы отчисляли четыре процента от стоимости каждой путевки и курсовки на развитие общекурортной инфраструктуры. По нынешнему курсу сумма курортного сбора составляла бы 70-80 млн. руб. в год. Именно на эти деньги и благоустраивали в то время курорт. Значит, необходимо и сейчас опираться на поло- жительный опыт прошлых лет.

Хотя были и пессимистические предположения, что люди, узнав о новом налоге на курортах Кавминвод, предпочтут поехать на отдых в другие регионы или за границу. Однако, как показывает анализ, проблема не в сумме курортного сбора, при нынешних ценах на путевки в санатории дополнительные 50 руб. в сутки почти никого не обременят. Дело в принципе - отдыхающим и туристам не хочется дополнительно оплачивать сверх того, на что они рассчитывали. Но интенсивная грамотная разъяснительная работа в санаториях, профилакториях и гостиницах, взимающих курортный сбор, а также в средствах массовой информации, позволяет нейтрализовать возможное непонимание. И если в 2017 году на КМВ отдохнули и оздоровились 998 тыс. отдыхающих, то в 2018 году курорт принял уже 1,5 млн. человек. На Кавминводах среднегодовая загрузка санаториев составляет 87,9\%, это самый высокий показатель по курортам страны [4]. Отдыхающих и туристов Кавминвод убеждали в том, что курортный сбор поступает на специальный счет и все средства пойдут на улучшение инфраструктуры курорта, т.е. условий их отдыха в санаторно-курортном комплексе. В результате, отдыхающие и туристы курортный сбор стали спокойно платить почти все, причем, эти же люди охотно приезжали на Кавминводы повторно. Операторы во всех четырех городах-курортах в 2018 году зафиксировали рост турпотока.

Значит, людей, желающих укрепить свое здоровье, не остановит незначительный для них курортный сбор. А курорту - ощутимый источник финансирования для дальнейшего развития инфраструктуры, чем в последующем и воспользуются эти же курортники и гости, а также их дети и внуки.

В столице СКФО г. Пятигорске на прессконференции главы городов-курортов Кавминвод подвели предварительные итоги эксперимента по развитию курортной инфраструктуры, обсудили возникшие проблемы и наметили пути их решения.

Предвидя положительное внедрение данного эксперимента на рекреационной территории, решение Губернатора, Думы и Правительства Ставропольского края оказалось удачным: выделять авансом из регионального и местных бюджетов в начале года денежные средства городам-курортам, соответствующие суммам, 
которые планировали получить от курортного сбора. Это позволит муниципалитетам безотлагательно заняться проектированием объектов курортной инфраструктуры, организацией конкурсных процедур среди подрядчиков и сразу приступить к полномасштабным работам.

Таким образом, в целом, можно уже сейчас утверждать, что эксперимент положит начало новому толчку в развитии и благоустройстве городов-курортов КМВ и в целом Ставропольского края.

Для обеспечения эффективности эксперимента считаем необходимым:

- обеспечить более строгий учет и контроль за сдачей в наём частного жилья в городахкурортах, что увеличит общую сумму курортно- го сбора;

- усилить внимание финансовому контролю (в том числе народному, по опыту прошлых лет) за поступлением и расходованием средств курортного сбора, профессионально грамотно, беспристрастно проверять каждую смету на строительство и реконструкцию объектов цены и тарифы, оплату труда, транспортные расходы и др., поставщиков и подрядчиков, закрыв все лазейки для недобросовестных людей, желающих поживиться за счет народных средств, собираемых на благоустройство курорта;

- соблюдать целенаправленное использование средств курортного сбора, но с учетом и других курортных объектов, подлежащих реконструкции.

\section{Библиографический список}

1. Федеральный закон от 29.07.2017 № 214-Ф3 «О проведении эксперимента по развитию курортной инфраструктуры в республике Крым, Алтайском крае, Краснодарском крае и Ставропольском крае».

2. Закон Ставропольского края от 08.12.2017 г. № 130-К3 «О некоторых вопросах проведения эксперимента по развитию курортной инфраструктуры в Ставропольском крае».

3. Закон Ставропольского края от 10 апреля 2008 г. № 20-кз «Об административных правонарушениях в Ставропольском крае».

4. Курорт региона Ставропольского края http://www.kurort26.ru/ 